\title{
RESTORATIVE JUSTICE SEBAGAI MEKANISME PENYELESAIAN TINDAK PIDANA KEKERASAN DALAM RUMAH TANGGA
}

\author{
Oleh: \\ Andro Giovani Ginting1), Vici UtomoSimatupang2) \\ dan Sonya Arini Batubara 3) \\ Universitas Prima Indonesia, Medan1,2,3) \\ E-Mail: \\ androginting8@gmail.com ${ }^{1)}$,vickywrsatria@.com ${ }^{2)}$ \\ sonyaairinibatubara@unprimdn.ac.id 3)
}

\begin{abstract}
There are many domestic violence settlements that do not satisfy the sense of justice, especially for the victims and subordinates in household. The result of this dissertation showed: first, the settlement of domestic violence in fact was settled by Act No. 23 of 2004 as lex specialis. The setlements of domestic violence cases based on that rule, empirically emphasized more on the criminal sanction, so that the purpose of preventive, protective and consolidative was not fulfilled. Second, the research concluded that domestic violence was a case with multidimensional settlement because there was the scope of the civil and criminal sphere on the other side. Therefore, it needed a medium in the system that could accommodate the completion of the case, one of which was restorativejustice approach.
\end{abstract}

Keywords: crime, domestic violence, criminal justice system, restorative justice

\section{PENDAHULUAN}

\section{a. Latar Belakang}

Restorative Justice merupakan suatu pendekatan untuk peradilan yang berfokus pada kebutuhan korban dan pelaku kejahatan, serta melibatkan peran serta masyarakat, bukan untuk menjalankan prinsip penghukuman terhadap pelaku disertai dengan pertimbangan hakim.

Setiap orang berhak menerima perlindungan atas dirinya pribadi dan perlindungan atas keluarga,martabat,kehormatan,dan harta benda yang dia miliki serta berhak mendapatkan rasa nyaman dan perlindungan dari berbagai ancaman yang dimana telah diatur dalam Pasal 28 G ayat (1) UUD 1945 amandemen ke dua".

Prinsip Restorative Justice proses penyelesaian tindakan pelanggaran hukum yang terjadi dilakukan dengan membawa korban dan pelaku bersamasama berbicara. Restorative Justice merupakan suatu pendekatan untuk peradilan yang berfokus pada kebutuhan para korban dan pelaku, serta masyarakat yang terlibat, bukan untuk menjalankan prinsip penghukuman terhadap pelaku.

Proses Restorative Justice mempunyai tujuan sebagai berikut:

1. Bertanggungjawab atas konsekuensi dari tindakan merekam dan berkomitmen untuk perbaikan/reparasi.

2. Langkah-langkah korban setuju untuk terlibat dalam proses yang dapat dilakukan dengan aman, memahami bahwa perbuatan mereka telah mempengaruhi korban dan orang lain, untuk kemudian menghasilkan kepuasan. 
3. Pelanggaran fleksibel yang disepakati oleh para pihak yang menekankan untuk memperbaiki kerusakan yang dilakukan dan secepat mungkin juga mencegah pelanggaran.

4. Pelanggar membuat komitmen mereka untuk memperbaiki kerusakan dan melakukan dan berusaha untuk mengatasi faktorfaktor prilaku mereka; dan

5. Korban dan pelaku baik memahami dinamika yang mengarah ke insiden tertentu memperoleh hasil akhir dan integrasi/kembali bergabung dalam masyarakat.

\section{b. Rumusan Masalah}

Berdasarkan konteks latar belakang masalah yang telah diuraikan diatas maka dalam penelitian ini dapat dirumuskan identifikasi masalah sebagai berikut:

1. Bagaimana penerapan Restorative Justice dalam penyelesaian tindak pidana kekerasan dalam rumah tangga?

2. Bagaimana upaya pelaksanaan Restorative Justice sebagai alternatif penyelesaian tindak pidana dalam rumahtangga?

3. Bagaimana mekanisme secara Restorative Justice perkara dalam rumah tangga berdasarkan sistem hukum di Indonesia?

\section{METODE PELAKSANAAN}

1. Jenis dan Sifat Penelitian

Penelitian merupakan penerapan metode yang telah ditentukan dalam pembuatan skripsi. Jenis penelitian yang digunakan penulis dalam skripsi ini adalah metode penelitian normatif. Penelitian hukum normatif atau penilitian perpustakaan ini merupakan penelitian yang mengkaji studi dokumen, yakni menggunakan berbagai data sekunder seperti peraturan perundang-undangan, keputusan pengadilan, teori hukum, dan dapat berupa pendapat para sarjana.

Sifat penelitian yang dipergunakan dalam skripsi ini adalah sifat penelitian deskriptif, dimana sifat penelitian ini mengungkapkan peraturan perundang-undangan yang berkaitan dengan teori-teori hukum sebagai objek penelitian. Demikian juga hukum dalam pelaksanaannya didalam masyarakatyang berkenaan dengan objek penelitian.

2. Sumber Bahan Hukum

Sumber bahan hukum yang digunakan dalam penelitian ini terdiri dari:

a. Bahan hukum primer yaitu bahan-bahan hukum yang mengikat dan mencakup peraturan perundang-undangan yang terkait dengan masalah yang akan diteliti seperti: UU nomor 11 tahun 2012 tentang Sistem Peradilan Pidana Anak, UU nomor 23 tahun 2004 tentang Penghapusan Kekerasan Dalam Rumah Tangga dan Kitab Undang-Undang Hukum Pidana.

b. Bahan hukum sekunder yaitu bahan hukum yang berkaitan dengan bahan hukum primer seperti Putusan Pengadilan, hasil karya ilmiah para sarjana, hasilhasil penelitian yang berhubungan dengan Pertanggungjawaban Pidana.

c. Bahan hukum tersier yaitu bahan-bahan yang memberi petunjuk maupun penjelasan terhadap bahan hukum primer maupun sekunder seperti kamuskamus hukum, ensiklopedia, dan sebagainya. 
3. Teknik Pengumpulan Data

Teknik pengumpulan bahan hukum yang dipergunakan dalam penelitian ini adalah penelitian kepustakaan (library research), yaitu melalui penelusuran peraturan perundang-undangan, dokumen maupun buku serta karya ilmiah lainnya yang sesuai dengan objek yang akan diteliti.

4. Analisis Data

Suatu proses atau upaya pengolahan data menjadi sebuah informasi baru agar karakteristik data tersebut menjadi lebih mudah dimengerti dan berguna untuk solusi suatu permasalahan, khususnya yang berhubungan dengan penelitian.

\section{PENELITIAN DAN PEMBAHASAN}

1. Penerapan Restorative Justice Dalam Penyelesaian Tindak Pidana Kekerasan Dalam Rumah Tangga

A. Konsep Restorative Justice Dalam PenyelesaianTinakPidanaKDRT

Tujuan utama dari restorative justice itu sendiri adalah pencapaian keadilan yang seadil-adilnya terutama bagi semua pihakyang terlibat didalamnya, dantidak sekedar mengedepankan penghukuman. Impelementasi restorative justice dalam Sistem Peradilan Pidana adalah sejalan dengan Deklarasi PBB tahun 2000 tentang Prinsip-Prinsip Pokok tentang Penggunaan Program-Program Keadilan Restoratif dalam PermasalahanPermasalahan Pidana, Hal ini juga dipertegas oleh Deklarasi Wina tentang Tindak Pidana dan Keadilan. Model hukuman restoratif diperkenalkan karena sistem peradilan pidana dan pemidanaan yang sekarang berlaku menimbulkan masalah. Dalam sistem kepenjaraan sekarang tujuan pemberian hukuman adalah penjeraan, balas dendam, dan pemberian derita sebagai konsekuensi perbuatannya. Indikator penghukuman diukur dari sejauh mana narapidana (napi) tunduk pada peraturan penjara. Jadi, pendekatannya lebih ke keamanan (security approach). Selain pemenjaraan yang membawa akibat bagi keluaga napi, sistem yang berlaku sekarang dinilai tidak melegakan atau menyembuhkan korban. Apalagi proses hukumnya memakan waktu lama. Dalam penyelesaian pemidanaan restoratif akan melibatkan korban, keluarga dan pihak-pihak lain dalam menyelesaikan masalah. Disamping itu hal ini menuntut pelaku tindak pidana untuk bertanggung jawab memperbaiki kerugian yang ditimbulkan atas perbuatannya,dan penerapannya tidak gampang. Kalau hanya diterapkan di lingkungan Lapas, hasilnya tidak akan maksimal. Jadi, model restoratif harus dimulai dari kepolisian, saat pertama kali perkara disidik. Di kejaksaan dan pengadilan pun demikian. Satu hal lagi yang sulit adalah memulihkan derita korban, baik fisik maupun psikis.

Menurut Romli Atmasasmita, berkaitan dengan masalah kejahatan, maka kekerasan sering merupakan pelengkap dari bentuk kejahatan itu sendiri. Bahkan, dia telah membentuk suatu ciri tersendiri dalam khasanah tentang studi kejahatan. Semakin menggejala dan menyebar luas frekuensi kejahatan yang diikuti dengan kekerasan dalam masyarakat, maka semakin tebal keyakinan masyarakat akan penting dan seriusnya kejahatan semacam ini. Dengan demikian, pada gilirannya model kejahatan ini telah membentuk persepsi yang khas di kalangan masyarakat. Tidaklah berbeda kiranya jika kita analogikan dengan perbuatan suap dari tingkat yang paling rendah sampai tingkat suap paling canggih. 
Berkaitan dengan kekerasan, yang kemudian dihubungkan dengan tingkah laku sebagaimana diapaparkan diatas adalah sangat wajar apabila kekerasan itu bisa timbul dalam kultur. Wolfgang dan Ferracuti menganggapnya sebagai teori subkultur kekerasan, yang pada intinya mengajarkan bahwa tiap penduduk yang terdiri atas kelompok etnik tertentu dan kelas-kelas tertentu memiliki sikap yang berbeda-beda tentang penggunaan kekerasan. Sikap yang mendukung penggunaan kekerasan diwujudkan ke dalam seperangkat norma yang sudah melembaga dalam kelompok tertentu dalam masyarakat.

B. Perkembangan Restorative Justice Berdasarkan UU NO. 23/2004 Tentang Penghapusan KDRT

Sebelum lahirnya Undang-Undang nomor 23 Tahun 2004, penyelesaian perkara kekerasan dalam rumah tangga lebih banyak menngunakan ketentuan lex generalis, misalnya penggunaan Pasal 351 ayat(1) dan Pasal 356 ke-1 KUHP. Padahal secara teori, kekerasan rumah tangga tidak hanya berupa kekerasan fisik semata, teteapi juga kekerasan psikis, kekerasan seksual, dan kekerasan ekonomi. Sehingga dengan melihat pengaturan yang ada di dalam KUHP sebagai lex generalis, tidak dapat menyelesaikan permasalahan kekerasan psikis, kekerasan seksual dan kekerasan ekonomi. Undang-Undang nomor 23 Tahun 2004 cukup memberikan pembatasan gerak bagi pelaku tindak kekerasan dalam rumah tangga.

Undang-undang ini dilatarbelakangi oleh pola pikir bahwa kekerasan dalam rumah tangga merupakan pelanggaran hak asasi manusia dan kejahatan terhadap martabat kemanusiaan serta bentuk diskriminasi yang harus dihapus. UUinijuga tidak menutup mata terhadap sebagian besar kejadian yang menjadikan perempuan sebagai korban dalam kekerasan, sehingga sudah sepatutnyalah apabila negara dan/atau masyarakat memberikan perlindungan.

Didalam penjelasan umumnya, UU ini menyampaikan bahwa pembaharuan hukum yang berpihak pada kelompok rentan atau tersubordinasi khususnya perempuan, menjadi sangat diperlukan sehubungan dengan banyaknya kasus kekerasan, terutama dalam rumah tangga. Dengan begitu, UU ini menganggap dirinya adalah suatu pembaharuan hukum dari KUHP yang khusus mengatur dalam lingkup rumah tangga.

Alasan yang digunakan disini adalah kekerasan dalam rumah tangga itu mempunyai kekhasan dengan karakteristik sendiri sehingga perlu juga diatur secara khusus. Dengan demikian, setiap perbuatan yang dimaksudkan dalam batas lingkup rumah tangga dapat diselesaikan dengan menggunakan UU ini.

\section{Upaya Pelaksanaan Restorative Justice Sebagai Alternatif Penyelesaian Tindak Pidana Dalam Rumah Tangga}

A. Pelaksanaan RestorativeJustice Dalam KDRT

Upaya penghapusan KDRT tentunya menjadi agenda penting bagi negara. Kewajiban negara dalam melindungi warga Negara tertuang dalam pembukaan Undang-Undang Dasar Republik indonesia tahun 1945 alinea ke 4. Selanjutnya perlindungan terhadap perempuan terhadap KDRT dijabarkan dalam konstitusi ke dalam beberapa pasal, yaitu pasal 28 huruf $\mathrm{G}$ ayat (1), pasal 28 huruf I ayat(2), pasal 28 huruf $\mathrm{H}$ ayat (1), pasal 28 huruf $\mathrm{G}$ ayat (2), pasal 28 huruf A, pasal 27 ayat (1), pasal 28 huruf D ayat (1). 
Selaras dengan hal itu UU PKDRT menyebutkan beberapa tujuan penghapusan KDRT, yaitu:

1. Mencegah segala bentuk kekerasan dalam rumahtangga (tujuan preventif); 2. Melindungi korban kekerasan dalam rumah tangga (tujuan protektif);

3. Menindak pelaku kekerasan dalam rumah tangga (tujuan represi);

4. Memelihara keutuhan rumah tangga yang harmonis dan sejahtera (tujuan konsolidasi).

Dalam mengakomodir hal tersebut, UU PKDRT telah membawa kasus KDRT dari wilayah privat suamih-istri ke ranah publik. Lingkup rumah tangga tidak hanya suami-istri tetapi lebih diperluas lagi sesuai pasal 2 UU KDRT yaknitidak hanya kekerasan fisik, tetapi juga mencakup kekerasan psikis, penelantara rumah tangga, dan seksual.

\section{B. Restorative Justice Dalam KDRT}

Tony Marshall memberikan defenisi restorative justice sebagai "proses yang melibatkan semua pihak yang memiliki kepentingan dalam masalah pelangaran tertentu untuk datang bersama-sama menyelesaikan secara kolektif bagaimana menyikapi dan menyelesaikan akibat dari pelanggaran dan aplikasinya untuk masa depan.

Terdapat tiga prinsip yang menjadi pondasi bagi pelaksanaan restorative justice, diantaranya:

1. Keadilan yang di tuntut adalah adanya upaya pemulihan bagi pihak yang dirugikan.

2. Siapapun yang terlibat dan terkena dampak dari tindak pidana harus mendapat kesempatan untuk berpartisipasi penuh dalam menindaklanjutinya.

3. Pemerintah berperan dalam menciptakan ketertiban umum, sementara masyarakat membangun dan memelihara.

C. Konsep Mediasi Penal Dalam KDRT

Dalam penggunaan mediasi dapat telah ditentukan dalam UU No. 30 Tahun 1999 mengenai Arbitrase dan Alternatif Penyelesaian Sengketa. Secara umum, penyelesaian perkara diluar pengadilan mempunyai beberapa keuntungan, diantaranya:

1. Untuk mengurangi kemacetan dan penumpukkan perkara(court congestion) di lembaga peradilan.

2. Meningkatkan keterlibatan masyarakat (desesntralisasi hukum) atau memberdayakan pihaka-pihak yang bersengketa dalam proses penyelesaian sengketa.

3. Meperlancarjalurkeadilan(acces to justice) dimasyarakat.

4. Untuk memberikan kesempatan bagi tercapainya penyelesaian sengketa yang menghasilkan keputusan yang dapat diterima oleh semua pihak.

5. Penyelesaian perkara lebih cepat dan biaya murah.

6. Bersifat tertutup/rahasia.

7. Lebih tinggi kemungkinan untuk melaksanakan kesepakatan.

\section{Mekanisme Secara Restorative Justice Perkara Dalam Rumah Tangga Berdasarkan Sistem Hukum di Indonesia}

A. Kewajiban Masyarakat Dan Pemerintah Ditinjau Dari Pasal 15 Uu No.23 Tahun 2004 Tentang PKDRT

Setiap masyarakat wajib melakukan upaya-upaya pencegahan terjadinya kekerasan dalam rumah tangga sesuai batas kemampuanya jika mengetahui atau melihat perkara ini secara langsung,dan hal ini sudah diatur 
dalam pasal 15 UU No 23 /2004 tentang Penghapusan Kekerasan Dalam Rumah Tangga. Dalam pasal tersebut peran masyarakat sangat diperlukan untuk :

1. Mencegah berlangsungnya tindak pidana;

2. Memberikan perlindungan kepada korban;

3. Memberikan pertolongan darurat; dan

4. Membantu proses pengajuan permohonan penetapan perlindungan.

Secara teori, terdapat berbagai macam bentuk musyawarah yang dapat diterapkan dalam konteks ini, antara lain negosiasi, mediasi, dan konsolidasi. Dari ketiga bentuk musyawarah ini, tampaknya negosiasi merupakan jalan yang paling baik, dipandang dari sisi penyelesaian internal kekeluargaan, karena perkara kekerasan rumah tangga tentu akan membuka peluang untuk mengungkapkan hal-hal yang dianggap aib di dalam keluarga. Secara kultural dalam masyarakat Indonesia pun, halhal yang dianggap aib oleh keluarga masih merupakan hal tabu untuk dikemukakan di hadapanumum.

B. Perlindungan Korban Tindak Pidana KDRT Berdasarkan UU NO.

23 Tahun 2004

Pengaturan penyelesaian perkara kekerasan dalam rumah tangga pada kenyataannya diselesaikan dengan peraturan yang lex generalis dan peraturan yang lex specialis. Sebelum lahirnya Undang-Undang Nomor 23 Tahun 2004, penyelesaian perkara

kekerasan dalam rumah tangga lebih banyak menggunakan ketentuan lex generalis, misalnya penggunaan Pasal 351 ayat (1) dan Pasal 356 ke-1 KUHP.

Padahal secara teori, kekerasan rumah tangga tidak hanya berupa kekerasan fisik semata, tetapi juga kekerasan psikis, kekerasan seksual, dan kekerasan ekonomi. Sehingga dengan melihat pengaturan yang ada di dalam KUHP sebagai lex generalis, tidak dapat menyelesaikan permasalahan kekerasan psikis, kekerasan seksual dan kekerasan ekonomi. Untuk memperbaiki kelemahan yang ada di dalam tubuh lex generalis tersebut, lahirlah Undang-Undang No. 23 Tahun 2004 yang secara khusus mengatur mengenai kekerasan dalam lingkup rumah tangga. Undang-Undang ini cukup memberikan pembatasan gerak bagi pelaku tindak kekerasan dalam rumah tangga.

Undang-undang ini dilatarbelakangi oleh pola pikir bahwa kekerasan dalam rumah tangga merupakan pelanggaran hak asasi manusia dan kejahatan terhadap martabat kemanusiaan serta bentuk diskriminasi yang harus dihapus. Undang-undang ini juga tidak menutup mata terhadap sebagian besar kejadian yang menjadikan perempuan sebagai korban dalam kekerasan, sehingga sudah sepatutnyalah apabila negara dan/atau masyarakat memberikan perlindungan. Dengan begitu, undang-undang ini menganggap bahwa dirinya adalah suatu pembaharuan hukum dari Kitab UndangUndang Hukum Pidana yang khusus mengatur dalam lingkup rumah tangga. Alasan yang digunakan disini adalah kekerasan dalam rumah tangga itu mempunyai kekhasan dengan karakteristik sendiri sehingga perlu juga diatur secara khusus. Dengan demikian, setiap perbuatan yang dimaksudkan di atas dalam batas lingkup rumah tangga dapat diselesaikan dengan menggunakan undang-undang ini.

\section{KESIMPULAN DANSARAN}

\section{a. Kesimpulan}

1. Penyelesaian perkara kekerasan dalam rumah tangga pada kenyataannya diselesaikan dengan peraturan yang lex generalis dan peraturan yang lex 
specialis. Meskipun dikatakan bahwa Undang-Undang No. 23 Tahun 2004 merupakan pembaharuan hukum, akan tetapi akan lebih baik apabila pembentukan undangundang tersebut menggunakan prinsip dalam teori "hukum sebagai sarana pembaharuan masyarakat dan birokrasi" atau "law as a tool of social and bereucratic engineering".

2. Penelitian ini telah menyimpulkan bahwa kekerasan dalam rumah tangga merupakan perkara dengan multi dimensi penyelesaian, mengingat di satu sisi perkara ini berkaitan dengan lingkup perdata dan di sisi lain berkaitan dengan lingkup pidana

3. Untuk menentukan model restorative justice yang tepat yang akan menjadi bagian dari Sistem Peradilan Pidana Indonesia, Penulis mengadopsi pandangan teori hukum pembangunan yakni ketertiban atau keteraturan dalam rangka pembaharuan atau pembangunan merupakan sesuatu yang diinginkan bahkan dipandang mutlak adanya, serta hukum dalam arti kaidah atau peraturan hukum memang dapat berfungsi sebagai alat pengatur atau sarana pembangunan dalam penyalur arah kegiatan manusia yang dikehendaki ke arah pembaharuan. Mekanisme restorative justice sebagai bagian implementasi dari model di atas, dapat dilakukan dalam beberapa mekanisme tergantung situasi dan kondisi yang ada dan bahkan ada yang mengkombinasikan satu mekanisme dengan yang lain.

\section{b. Saran}

1. Dengan berlandaskan pada tinjauan teori di dalam penelitian ini, sebaiknya penyelesaian perkara kekerasan dalam rumah tangga dilakukan dengan menggunakan pendekatan restorative justice.

2 Pembuat undang-undang segera melakukan perubahan di dalam tubuh UndangUndang No. 23Tahun 2004, mengenai model dan mekanisme restorative justice yang diadopsi dari pandangan John Braithwaite, yang dikenal dengan model systemic. Hanya saja Sistem Peradilan Pidana Indonesia lebih sesuai menggunakan mekanisme mediasi untuk mencapai tujuan hukum, melalui pendekatan restorative justice sebagai landasan aplikatifnya

3. Dengan pengubahan metode tersebut di atas di dalam penanganan perkara kekerasan dalam rumah tangga, sebenarnya secara tidak langsung telah mensosialisasikan persepsi restorative justice dalam perkara tersebut, terutama bagi penegak hukum yang masih berwacana keadilan konvensional serta masyarakat. Pengembangan restorative justice ke depan, tidak hanya terbatas pada perkara kekerasan dalam rumah tangga saja, tetapi dapat diperluas kepada perkara-perkara lain yang memerlukan keadilan yang bersifat restoratif untuk pencapaian penyelesaian permasalahan secara komprehensif dan holistik. 


\section{DAFTAR PUSTAKA}

\section{A. Buku}

Adi

Sulistyono.

2006.

Mengembangkan Paradigma Nonlitigasi di Indonesia. UNS Press. Surakarta.

Marlina, Peradilan Pidana Anak di

Indonesia: Pengembangan Konsep

Diversi dan Restorative

Justice, Cetakan Pertama, Refika Aditama, Bandung, 2009.

Mochtar Kusumaatmadja. 2002. Konsep-Konsep dalam

Pembangunan. Bandung.

Romli Atmasasmita. 2005. Teori Dan

Kapita Selekta Kriminologi. Refika Aditama. Bandung.

Romli Atmasasmita. Reformasi Hukum, Hak Asasi Manusia Dan Penegakan Hukum, Mandar Maju, Bandung.

Yusi Amdani, Konsep Restorative Justice Dalam Penyelesaian Perkara Tindak Pidana Pencurian Oleh Anak Berbasis Hukum Islam dan Adat Aceh, 2016.

B. Peraturan Perundang-Undangan Kitab Undang-Undang Hukum Pidana Undang-Undang Nomor 23 Tahun 2014 Tentang Penghapusan Kekerasan Dalam Rumah Tangga

\section{Situs Website}

https://media.neliti.com/media/ publications/56839-ID-konseprestorative-justice-dalampenyele.pdf, Minggu, 20 Mei 2018, diakses pukul 15:00.

https://idtesis.com/pengertianpenelitian-hukum-normatif-adalah, Selasa, 10juli 2018, pukul 13.25 .

http://www.komnasperempuan. or.id/publikasi/indonesia/kampanye \%2016\%2ohari\%2

02010/materi\%20fix/Press\%20 Backgrounder\%2okekerasan\%2oSek sual,\%2 okenali

\%20dan\%20Tangani

Final\%2024\%20November\%202 o10.pdf,di akses" pada tanggal 24 desember 2012.

Manshurzikri, "Restorative justice Sebagai Mekanisme Penyelesaian Perkarayang Mengedepankan Kepentingan Perempuan Sebagai Korban Kekerasan Seksual http://manshurzikri.wordpress.c om/2011/o6/o1/restorative-justicesebagai mekanismepenyelesaian-perkara-yangmengedepankan-kepentinganperempuan- sebagai-korbankekerasan-seksual, akses pada tanggal 1 Januari 2019. 